\title{
Critical role of medical education among dentists and dental students on HIV/AIDS: a systematic review
}

\author{
Irna Sufiawati, Eliza K.M. Munthe \\ Faculty of Dentistry, Universitas Padjajaran, Indonesia
}

\begin{abstract}
Dentists and dental students have an ethical responsibility to provide treatment for human immunodeficiency virus (HIV) patients, since oral lesions are common to occur in HIV patients. The purpose of this paper was to present a systematic review of current published literature regarding the basic medical knowledge of HIV/acquired immune deficiency syndrome (AIDS) among dentists and dental students. HIV infection has a high-rate of morbidity and mortality, and this disease is a devastating public health issue. A true understanding of HIV/AIDS is still lacking in developing countries. Among dentist $69.8 \%$ reported that absence of knowledge was their main concern in treating HIV patients. High-risk category for cross-contamination occurs in dentists and dental students. Inadequate knowledge of transmission process, diagnosis, treatment, and ignorance about the disease has led to a fear and HIV phobia. Negative attitude and willingness to treat HIV patients are influenced by lack of knowledge. The positive result in providing care for HIV patients has been proven through appropriate training of dentists in terms of HIV patient care in clinical experience. The knowledge and practice of dentists and dental students regarding the disease are strengthened by an innovative education. Knowledge of HIV/AIDS and positive attitude towards people with HIV/AIDS are crucial for dental students. There is a need for continued medical education for dentists and dental students on issues related to HIV infection.
\end{abstract}

HIV AIDS Rev 2020; 19, 1: 1-7

DOI: https://doi.org/10.5114/hivar.2020.93236

Key words: attitude, dentist, dental student, HIV, knowledge.

\section{Introduction}

The United Nations Programme on AIDS (UNAIDS) from 2017 reported that there were approximately 36.9 million people (range, 31.1-43.9 million) living with human immunodeficiency virus (HIV)/acquired immune deficiency syndrome (AIDS). Despite new cases, HIV infections among adults have declined, but HIV/AIDS remains one of the most significant public health challenges, particularly in many developing countries (low- and middle-income countries) [1]. The burden of HIV infection continues to increase in those countries and becomes crucial for healthcare professionals. Dental health care providers and dental students are the group of professionals who are at high-risk of work-related infections [2].

Stigma and discrimination against HIV/AIDS patients play an important role in reducing healthcare efforts to control the disease [3]. Many studies reported that dentists and dental students feel uncomfortable treating patients with HIV and AIDS [4-8]. Splashes of blood and saliva during
Address for correspondence: Dr. Irna Sufiawati,

Faculty of Dentistry, Universitas Padjajaran, Indonesia,

e-mail: irna.sufiawati@fkg.unpad.ac.id
Article history:

Received: 01.03.2019

Received in revised form: 07.07.2019

Accepted: 08.07.2019

Available online: 06.02.2020
International Journal of HIV-Related Problems

HIV \& AIDS

R e v i e w 
dental therapeutic procedures usually occurs, which may contain infectious pathogenic microorganisms; however, the risk of HIV transmission during dental procedures remains very low [9]. A lack of adequate knowledge about HIV transmission, awareness, and risk perceptions about HIV/AIDS can act as barriers to appropriate treatment of HIV-infected patients in healthcare settings [3]. Unwillingness to treat HIV/AIDS patients may cause oral healthcare to diminish and the access to dental services may be a necessity that cannot be obtained.

Oral healthcare is an important aspect of medical care for people living with HIV that can improve their quality of life, particularly dentists who have an impact on the course of the disease. Quality of life of HIV patients can be reduced and influenced by the presence of diseases in the oral cavity $[10,11]$. In the early stages of the disease, most lesions of HIV infection present orally. Aming HIV-infected individuals $60-70 \%$ show early signs of HIV infection in the form of oral manifestations such as oropharyngeal candidiasis (OPC), Kaposi's sarcoma, linear gingival erythema (LGE), oral hairy leukoplakia (OHL), which are independent of CD4 count status and a prognostic value [12-14]. Early detection and referring HIV-suspected patients to a physician for an early treatment are the responsibility of dentists. International published papers provide evidence that support dentists' willingness to conduct HIV screening $[15,16]$. Positive approach combined with the level of knowledge has been widely investigated and proved that negative attitude can be changed through continuous education. It is generally understood that the level of knowledge affects attitudes. Previous studies indicate that an increase in the willingness to take care of HIV-infected patients occur when the knowledge of HIV also increases [17, 18]. A total of $69.8 \%$ of the dentists reported that the lack of proper knowledge and training in handling HIV-infected patients were their main concerns in treating those patients [19]. There is also evidence that the changes of health professionals' attitudes toward HIV patients cannot occur by legal measures only. An increase in awareness associated with HIV patients and the possibility of transmission of infection improve dental approaches in the care of patients with HIV [8]. There have been many studies evaluating the attitudes of dental students influenced by educational efforts with respect to treating HIV/AIDS patients.

The aim of the systematic review was to analyze levels of knowledge and attitude among dentist and dental students regarding HIV/AIDS. In this study, keywords such as HIV, AIDS, knowledge, attitude, dentists, dental students were used in the search, and data were collected from PubMed, Science Direct, and BioMed databases. Articles published between 2007 and 2017 on appropriate dentists' and dental students' knowledge and attitude were regarded as inclusion criteria of the study. Following database searching, authentic journals were hand-searched for additional papers. Articles with a weak relationship to the study were not included, and references of the selected articles were researched to evaluate all available literature and to find more related papers.
In addition to the obtained articles, relevant documents from international organizations (AIDS UN and WHO) were acquired. Inclusion criteria were the studies, which aimed to determine knowledge and attitude of dentists and dental students regarding HIV/AIDS conducted within the last 10 years.

\section{Assessment of knowledge and attitudes of dentists and dental students regarding HIV/AIDS}

Our study revealed several surprising facts about knowledge, attitude, and willingness of dentists and dental students to treat HIV/AIDS patients. The majority of dentists and dental students demonstrated high level of knowledge, but the assessment of their attitude was negative, and many dentists did not wanted to proceed with oral healthcare. Although the dentists and dental students presented excellent knowledge about HIV/AIDS, the majority of them exhibited a fear of contracting HIV from needle-stick injury and saliva while treating these patients.

Scores of dentists' and dental students' knowledge, and attitudes toward HIV/AIDS are summarized in Table 1. Eleven articles had studied dentists' and dental students' knowledge and attitudes regarding HIV/AIDS. Overall, the estimation of prevalence was 0.682 , which means that about $68.2 \%$ of participants had a good knowledge score regarding HIV/ AIDS. The assessed prevalence of knowledge among dental students and dentists were 0.730 and 0.632 , respectively, which mean that about $73.0 \%$ of dental students had better knowledge than dentists (63.2\%), but it was not statistically significant ( $p=0.146$, Tables 2 and 3 ). Nineteenth studies were included to evaluate the attitude of dentists and dental students for dental treatment of HIV/AIDS patients. The results showed that, overall, the estimation of prevalence was 0.421 , which means that about $42.1 \%$ of them had a good attitude score regarding HIV/AIDS, but $44.8 \%$ of dental students had a better attitude than dentists who presented only $38.3 \%$ of positive attitude score regarding HIV/AIDS; however, it was not statistically significant [4, 6-8, 19-33].

The analysis of knowledge about needle-stick injury and possible HIV transmission between dental students and dentists is presented in Table 2. Several studies showed various results on the knowledge about needle-stick injury and possible HIV transmission. Generally, the estimate of prevalence was 0.836 , which means that about $83.6 \%$ of participants had a good score regarding knowledge of needle-stick injury and possible HIV transmission. However, the estimated prevalence of dental student's knowledge was 0.942 , which mean that about $94.2 \%$ of dental students had a better knowledge than dentists, with $65.8 \%$ of knowledge score $[7,19,22,23,25,31,33]$. To evaluate the knowledge of HIV transmission by saliva in dental students and dentists, we included five studies, which showed various results (Table 3). Overall, the estimate of prevalence was 0.622 , which means that about $62.2 \%$ of participants had a good score regarding the knowledge of HIV transmission by saliva; however, 
Table 1. Knowledge and attitudes of dentists and dental students regarding HIV/AIDS

\begin{tabular}{|c|c|c|c|c|c|c|c|c|c|}
\hline \multirow[t]{3}{*}{ Author } & \multirow[t]{3}{*}{ Year } & \multirow[t]{3}{*}{ Country } & \multirow[t]{3}{*}{ Sample } & \multirow[t]{3}{*}{$N$} & \multirow[t]{3}{*}{$\begin{array}{l}\text { Knowledge } \\
\text { score (\%) }\end{array}$} & \multirow[t]{3}{*}{$\begin{array}{l}\text { Attitude } \\
\text { score (\%) }\end{array}$} & \multirow[t]{3}{*}{ Group } & \multirow{2}{*}{\multicolumn{2}{|c|}{$\begin{array}{c}\begin{array}{c}\text { Effect size and } 95 \% \\
\text { interval }\end{array} \\
\text { Point estimate }\end{array}$}} \\
\hline & & & & & & & & & \\
\hline & & & & & & & & Knowledge & Attitude \\
\hline Dhanya et al. [20] & 2017 & India & $\mathrm{D}$ & 206 & 54.55 (weak) & 55.71 (negative) & $\mathrm{D}$ & 0.623 & 0.383 \\
\hline Wang et al. [21] & 2015 & China & $\mathrm{D}$ & 477 & 69.00 (good) & 50.00 (negative) & - & - & - \\
\hline Oberoi et al. [22] & 2014 & India & $\mathrm{D}$ & 127 & 76.75 (good) & 71.63 (positive) & - & - & - \\
\hline Kadeh et al. [23] & 2014 & Iran & $\mathrm{D}$ & 100 & 65.00 (good) & 64.00 (negative) & - & - & - \\
\hline Prabhu et al. [19] & 2014 & India & $\mathrm{D}$ & 102 & 78.65 (good) & 31.84 (positive) & - & - & - \\
\hline Khosravanifard [8] & 2012 & Iran & $\mathrm{D}$ & 300 & $\begin{array}{c}22.70 \text { (good) } \\
24.0 \text { (average) }\end{array}$ & 85.30 (negative) & - & - & - \\
\hline Park et al. [24] & 2010 & Korea & $\mathrm{D}$ & 475 & $\begin{array}{l}81.60 \text { (good) } \\
53.30 \text { (weak) }\end{array}$ & $\begin{array}{l}11.00 \text { (positive) } \\
14.70 \text { (positive) }\end{array}$ & - & - & - \\
\hline Singh et al. [4] & 2017 & Malaysia & DS & 186 & $\begin{array}{c}41.60 \text { (excellent) } \\
56.20 \text { (good) }\end{array}$ & 18.00 (positive) & DS & 0.730 & 0.448 \\
\hline Yousuf et al. [6] & 2016 & India & DS & 213 & 72.02 (good) & $\begin{array}{l}65.17 \text { (positive) } \\
34.83 \text { (negative) }\end{array}$ & - & - & - \\
\hline Li et al. [25] & 2016 & China & DS & 95 & $\begin{array}{c}2.10 \text { (excellent) } \\
51.60 \text { (good) } \\
42.10 \text { (moderate) } \\
4.20 \text { (weak) }\end{array}$ & $\begin{array}{c}93.70 \text { (negative) } \\
2.10 \text { (positive) } \\
4.20 \text { (passive) }\end{array}$ & - & - & - \\
\hline $\begin{array}{l}\text { Rungsiyanont } \\
\text { et al. [26] }\end{array}$ & 2013 & Thailand & D, DS & 446 & $\begin{array}{l}61.60 \text { (good/DS) } \\
61.20 \text { (good/D) }\end{array}$ & $\begin{array}{l}51.31 \text { (negative) } \\
35.11 \text { (negative) }\end{array}$ & - & - & - \\
\hline $\begin{array}{l}\text { Aggarwal } \\
\text { et al. [27] }\end{array}$ & 2013 & India & DS & 460 & 78.80 (excellent) & 77.70 (positive) & - & - & - \\
\hline Aggarwal et al. [7] & 2012 & India & DS & 300 & 78.97 (good) & 75.00 (positive) & - & - & - \\
\hline Ryalat et al. [28] & 2011 & Jordanian & DS & 265 & $\begin{array}{l}\text { Generally } \\
\text { acceptable }\end{array}$ & 32.75 (negative) & - & - & - \\
\hline Myers [29] & 2012 & USA & DS & 215 & 45.00 (adequate) & 37.30 (positive) & - & - & - \\
\hline \multirow[t]{2}{*}{ Ellepola et al. [30] } & \multirow[t]{2}{*}{2011} & $\begin{array}{l}\text { Kuwait } \\
(\mathrm{KU})\end{array}$ & DS & 215 & $\begin{array}{l}\text { KU: } 58.36 \\
\text { (good) }\end{array}$ & $\begin{array}{l}\text { KU: } 52.40 \\
\text { (positive) }\end{array}$ & - & - & - \\
\hline & & $\begin{array}{l}\text { Sri Lanka } \\
\text { (UP) }\end{array}$ & & & $\begin{array}{l}\text { UP: } 55.60 \\
\text { (good) }\end{array}$ & $\begin{array}{l}\text { UP: } 68.40 \\
\text { (positive) }\end{array}$ & - & - & - \\
\hline Patil et al. [31] & 2011 & India & DS & 219 & 76.50 (excellent) & 62.90 (negative) & - & - & - \\
\hline Oboro et al. [32] & 2010 & Nigeria & DS & 150 & $\begin{array}{c}71.90 \text { (high) } \\
25.90 \text { (moderate) } \\
2.20 \text { (low) }\end{array}$ & 72.20 (negative) & - & - & - \\
\hline Sadeghi et al. [33] & 2009 & Iran & DS & 455 & 82.10 (excellent) & 57.40 (negative) & Overall & 0.682 & 0.421 \\
\hline
\end{tabular}

DS - dental students, $D$ - dentist

$76.6 \%$ of dentists had a better knowledge than dental students $-47.3 \%$ of knowledge score [19, 23, 24, 28, 31]. The anxiety of work-related exposure may explain the reason for such a negative attitude of the students for HIV/ AIDS patients.

The recognition of dentists and dental students about oral manifestation associated with the disease were at a good knowledge level. In total, there are 40 oral manifestations related to HIV infection reported. The lesions such as Kaposi's sarcoma, oral hairy leukoplakia, oral lesions of herpetic infections, and oral candidiasis requires more knowledge about the lesions as well as those less strongly associated with HIV such as oral melanotic hyperpigmentation and salivary gland disease. It should also be noted that although the lesions are strongly associated with HIV/AIDS, they are not exclusive to HIV/AIDS (Table 4). Overall assessment of knowledge about OPC was 0.963 , which means that about $96.3 \%$ of participants had a good score regarding OPC knowledge. Among dental students $96.4 \%$ had better knowledge than dentists, with only $96 \%$ of knowledge score, but 
Table 2. Knowledge of risk of HIV transmission through needle-stick injury

\begin{tabular}{l|c|c|c|c|c|c|c}
\hline Authors & Sample & $N$ & Year & Score (\%) & Groups & $\begin{array}{c}\text { Number } \\
\text { of studies }\end{array}$ & Effect size and 95\% interval \\
\cline { 6 - 8 } & & & & & & - & Point estimate \\
\hline Li et al. [25] & DS & 95 & 2015 & 97.9 & - & - \\
\hline Aggrawal et al. [7] & DS & 300 & 2012 & 5.0 & DS & 4 & 0.942 \\
\hline Patil et al. [31] & DS & 219 & 2011 & 97.5 & - & - & - \\
\hline Sadeghi et al. [33] & DS & 455 & 2009 & 91.7 & - & - & - \\
\hline Oberoi et al. [22] & D & 127 & 2014 & 60.0 & - & - & - \\
\hline Prabhu et al. [19] & D & 102 & 2014 & 96.3 & D & 3 & 0.658 \\
\hline Kadeh et al. [23] & D & 100 & 2014 & 64.0 & Overall & 7 & 0.836 \\
\hline
\end{tabular}

DS - dental students, $D$ - dentist

Table 3. Knowledge of risk of HIV transmission through saliva

\begin{tabular}{l|c|c|c|c|c|c|c}
\hline Authors & Sample & $N$ & Year & Score (\%) & Groups & $\begin{array}{c}\text { Number } \\
\text { of studies }\end{array}$ & Effect size and 95\% interval \\
\cline { 6 - 8 } & & & & & & & Point estimate \\
\hline Patil et al. [31] & DS & 219 & 2011 & 40.0 & DS & 2 & 0.473 \\
\hline Ryalat et al. [28] & DS & 265 & 2011 & 53.3 & - & - & - \\
\hline Kadeh et al. [23] & D & 100 & 2014 & 3.0 & - & - & - \\
\hline Prabhu et al. [19] & D & 102 & 2014 & 57.4 & D & 3 & 0.766 \\
\hline Park et al. [24] & D & 475 & 2011 & 86.5 & Overall & 5 & 0.622 \\
\hline
\end{tabular}

$D S$ - dental students, $D$ - dentist

Table 4. Knowledge about oral manifestation of HIV/AIDS

\begin{tabular}{|c|c|c|c|c|c|c|c|c|c|c|c|c|}
\hline \multirow[t]{2}{*}{ Authors } & \multirow[t]{2}{*}{ Sample } & \multirow[t]{2}{*}{ Year } & \multirow[t]{2}{*}{$N$} & \multirow{2}{*}{$\begin{array}{l}\text { OC } \\
\text { (\%) }\end{array}$} & \multirow{2}{*}{$\begin{array}{l}\text { KS } \\
\text { (\%) }\end{array}$} & \multirow{2}{*}{$\begin{array}{l}\mathrm{OHL} \\
\text { (\%) }\end{array}$} & \multirow{2}{*}{$\begin{array}{c}\mathrm{H} \\
(\%)\end{array}$} & \multirow[t]{2}{*}{ Group } & \multicolumn{4}{|c|}{ Effect size and $95 \%$ interval } \\
\hline & & & & & & & & & OC & KS & $\mathrm{OHL}$ & $\mathrm{H}$ \\
\hline Li et al. [25] & DS & 2016 & 95 & 96.8 & 100.0 & 98.8 & 78.0 & DS & 0.964 & 0.947 & 0.888 & 0.764 \\
\hline Aggrawal et al. [27] & DS & 2013 & 300 & 95.2 & 94.5 & 88.2 & 72.9 & - & - & - & - & - \\
\hline Patil et al. [31] & DS & 2009 & 219 & 98.1 & 93.8 & 82.2 & 79.2 & - & - & - & - & - \\
\hline Sadeghi et al. [33] & DS & 2014 & 455 & 97.7 & 95.2 & 96.0 & 86.7 & $\mathrm{D}$ & 0.960 & 0.905 & 0.908 & 0.836 \\
\hline Oberoi et al. [22] & $\mathrm{D}$ & 2014 & 127 & 95.0 & 86.0 & 85.0 & 81.0 & Overall & 0.963 & 0.931 & 0.896 & 0.797 \\
\hline
\end{tabular}

$D S$-dental students, $D$-dentist, $O C$ - oral candidiasis, $K S$ - Kaposi sarcoma, $O H L$ - oral hairy leukoplakia, $H$ - herpetic

93.1\% of them had a good score regarding the knowledge about Kaposi's sarcoma, whereas $94.7 \%$ of dental students had better knowledge than dentists $(90.5 \%$ of knowledge score). In general, $89.6 \%$ of participants had a good score concerning knowledge about oral hairy leukoplakia, with $90.8 \%$ of dentists better knowledge on OHL than dental students $-88.8 \%$ of knowledge score. Overall, the estimation point of knowledge about herpetic lesions was 0.797 , which means that about $79.7 \%$ of respondents had a good score of knowledge on herpetic lesions. $83.6 \%$ dentists had better knowledge than dental students, which had only $76.4 \%$ of knowledge score (Table 4) [22, 25, 27, 31, 33].

Dental students and dentists had an equal opinion that HIV/AIDS patients should be treated in dental centers, but felt that during the treatment, a certain precautions are required (Table 5). The analysis of the present study included evaluation of attitude of willingness to take care of HIV/AIDS patients and involved twelve studies. The estimated prevalence was 0.533 , which means that about $53.3 \%$ of participants had an average score regarding attitude of willingness to take care of HIV/AIDS patients. Among dentists $62.7 \%$ had a better attitude than dental students, which had $43.7 \%$ of attitude of willingness score [19-25, 27, 31-34]. The analysis to evaluate the attitude that HIV/AIDS patients require special dental clinic included six studies. The results showed that the estimation point was 0.437 , which means that about $43.7 \%$ of participants had a low score regarding attitude that HIV/AIDS patients require special dental clinic. About one third (36.2\%) dentists had better attitude than dental students $-47.6 \%$ of the score (Table 6 ) [18, 21, 23, 25, 28, 31].

Overestimation of the risk of HIV spreading was the main concern of dental students to provide dental treat- 
Table 5. Willingness to take care of HIV/AIDS patients

\begin{tabular}{l|c|c|c|c|c|c|c}
\hline Authors & Sample & $N$ & Year & Score (\%) & Groups & $\begin{array}{c}\text { Number } \\
\text { of studies }\end{array}$ & Effect size and 95\% interval \\
\cline { 4 - 8 } & & & & & & Point estimate \\
\hline Khan et al. [34] & DS & 481 & 2016 & 54.5 & DS & 6 & 0.437 \\
\hline Li et al. [25] & DS & 95 & 2015 & 63.2 & - & - & - \\
\hline Patil et al. [31] & DS & 219 & 2011 & 72.0 & - & - & - \\
\hline Aggarwal et al. [27] & DS & 460 & 2013 & 15.8 & - & - & - \\
\hline Oboro et al. [32] & DS & 150 & 2010 & 63.3 & - & - & - \\
\hline Sadeghi et al. [33] & DS & 455 & 2009 & 11.6 & - & - & - \\
\hline Dhanya et al. [20] & D & 206 & 2017 & 60.7 & D & 6 & - \\
\hline Wang et al. [21] & D & 477 & 2015 & 50.0 & - & - & - \\
\hline Oberoi et al. [22] & D & 127 & 2014 & 86.0 & - & - & - \\
\hline Kadeh et al. [23] & D & 100 & 2014 & 17.0 & - & - & - \\
\hline Prabhu et al. [19] & D & 102 & 2014 & 63.7 & - & - & - \\
\hline Park et al. [24] & D & 475 & 2011 & 86.5 & Overall & 12 & - \\
\hline
\end{tabular}

DS - dental students, $D$ - dentist

Table 6. Attitude towards special dental clinic requirement for HIV/AIDS patients

\begin{tabular}{l|c|c|c|c|c|c|c}
\hline Authors & Sample & $N$ & Year & Score (\%) & Groups & $\begin{array}{c}\text { Number } \\
\text { of studies }\end{array}$ & Effect size and 95\% interval \\
\cline { 5 - 8 } & & & & & & Point estimate \\
\hline Li et al. [25] & DS & 95 & 2015 & 6.8 & DS & 4 & 0.476 \\
\hline Jafari et al. [18] & DS & 55 & 2012 & 87.3 & - & - & - \\
\hline Patil et al. [31] & DS & 219 & 2011 & 51.0 & - & - & - \\
\hline Ryalat et al. [28] & DS & 265 & 2011 & 32.8 & - & - & - \\
\hline Wang et al. [21] & D & 477 & 2015 & 18.9 & D & 2 & 0.362 \\
\hline Kadeh et al. [23] & D & 100 & 2014 & 70.0 & Overall & 6 & 0.437 \\
\hline
\end{tabular}

DS - dental students, $D$ - dentist

Table 7. Attitude towards the fear of contracting HIV

\begin{tabular}{l|c|c|c|c|c|c|c}
\hline Authors & Sample & $\boldsymbol{N}$ & Year & Score (\%) & Groups & $\begin{array}{c}\text { Number of } \\
\text { studies }\end{array}$ & Effect size and 95\% interval \\
\cline { 3 - 7 } $\begin{array}{l}\text { Hammershock } \\
\text { et al. [37] }\end{array}$ & DS & 305 & 2014 & 34.9 & DS & 4 & Point estimate \\
\hline Jafari et al. [18] & DS & 55 & 2012 & 44.4 & - & - & 0.549 \\
\hline Sadeghi et al. [33] & DS & 455 & 2009 & 84.2 & - & - & - \\
\hline Khan et al. [34] & DS & 481 & 2016 & 48.8 & - & - & - \\
\hline Kadeh et al. [23] & D & 100 & 2014 & 95.0 & D & 2 & 0.710 \\
\hline Park et al. [24] & D & 475 & 2011 & 29.0 & Overall & 6 & 0.604
\end{tabular}

DS - dental students, $D$ - dentist

ment to HIV/AIDS patients. Moreover, overwhelming by fear of possible contagion was another reason for dental students, even though they had a good knowledge and clinical skills allowing them to address HIV patients [23]. The level of knowledge and clinical skills to address a patient cannot overcome students' fears and concerns about being infected with HIV [4]. Moreover, negative feelings and attitudes can refrain dentists and dental students from reaching their full potential as clinicians. There was inadequate ability to provide clinical care to patients, although the level of knowledge of dental students and dentists about the disease was relatively high. The ability of their knowledge and practical ex- 
perience to treat HIV/AIDS patients can be defeated by their own fear from contracting the disease. In our study, the evaluation of the fear of contracting HIV from patients included six studies. Overall, the estimation point was 0.604 , which means that about $60.4 \%$ of participants had a fear of contracting HIV from a patient. Seventy-one percent of dentists had more fear than dental students $-54.9 \%$ (Table 7).

A similar inconsistency between knowledge and attitudes indicating that negative attitudes of dentists and dental students toward patients with HIV are not only influenced by knowledge. Anxiety about patient's loss, difficulty dealing with anxious staff members, fear of the risk of HIV transmission, and financial problems with infection to control were the reasons for refusal in caring for HIV patients. The diverse cultural and social backgrounds influence their attitudes, not just factors such as the curriculum [30]. Specific strategies in dental healthcare arrangements are needed to prevent the risk of transmission of disease among dentists and dental students as well as from patients to patients [33]. The important role of dental students in the treatment of HIV patients is that they are the future healthcare providers. Increasing their knowledge about the processes of disease, manifestations in the oral cavity and mode of spreading, and diagnosis and management of HIV/AIDS patients are all very important to better understand and improve own attitude to HIV patients [25, 30, 33].

To date, the knowledge about pathogenesis, treatment and prognosis on HIV, and controlling infections should be completed appropriately using universal precautions and availability of post-exposure prophylaxis, which are important steps in the completion of solving this issues concerning dentists and dental students. Based on these findings, to cover the areas where knowledge seems to be lacking, more attention is needed to the topic. It is believed that the improvement of attitudes can be taught in dental schools [4, 30]. The changes in students' attitudes can be made by utilizing appropriate and innovative training methods. The comfort in treating vulnerable patients is most often associated with previous students' experiences. In addition, the increased future willingness to treat HIV/AIDS patients may seem to be influenced by experience and comfort.

\section{The importance of education in knowledge and attitudes to HIV/AIDS}

These findings support that educational and clinical experience in caring HIV/AIDS patients needs to be included in the dental curriculum $[8,18]$. This finding highlights that knowledge and attitudes to HIV or other infectious diseases in a class or workshop need to be included. The emphasis on ethical responsibility for the care of all patients in need is more important [24]. Efforts must be made to reduce negative attitudes to HIV/AIDS patients, in addition to increasing knowledge about HIV/AIDS. To eliminate false beliefs, information that showing facts about HIV virus and the spread of the disease should be widely available [30].
The risk of acquiring HIV infection during dental treatment has a high percentage because most of the HIV patients are unaware of HIV/AIDS disease status. It is necessary for dental professionals and supporting staff to have an adequate knowledge about HIV infection and AIDS. Dental professionals have an important role in early detection and referring suspected patients for their initial treatment. It is the ethical and moral responsibility of all dental professionals to treat HIV-positive patients in the same way like all other patients [6]. HIV-related oral conditions occur in the majority of HIV-positive people and are frequently misdiagnosed or inadequately treated [35]. It is essential that dental care is available for HIV patients, which is necessary for their health and well-being.

It has been reported that the curriculum of psychological aspects of treating HIV/AIDS patients is an effective method to improve the attitude of students towards HIV/ AIDS patients [36]. A comprehensive educational and motivational program for dentists and dental students is needed to ensure adequate care of HIV/AIDS patients.

Willingness to care for HIV/AIDS patients is determined by knowledge and attitude related to HIV/AIDS. Negative attitudes to HIV-infected patients might be caused by insufficient knowledge. It has been reported that there is a correlation between the increased knowledge of disease and the increase of attitudes toward patients with HIV/AIDS. The fear in treating HIV-infected patients can be reduced with the increase of knowledge [9]. Dental students' understanding of infectious disease control methods and preventing the spread of HIV will increase as their knowledge increases [11]. Poverty and discrimination that express unwillingness to take care of HIV/AIDS patients and referring to other centers or support groups are the reasons why oral healthcare and access to dental services consistently remain reluctant to answer the needs of HIV/AIDS patients.

\section{Conclusions}

Dental professionals need to be well-informed and dedicated in early detection of HIV infection, and willing to treat patients with HIV/AIDS in a compassionate and comprehensive way. The HIV/AIDS program and advanced medical education need to be developed to improve their knowledge, attitudes, and behaviors related to HIV/AIDS patients, particularly in developing countries.

\section{Conflict of interest}

The authors declare no conflict of interest with respect to the research, authorship, and/or publication of this article.

\section{References}

1. UNAIDS (Joint United Nations Programme on HIV/AIDS). UNAIDS DATA 2018. Geneva, Switzerland. Accessed on September 18, 2018. Available at: https://www.unaids.org/sites/default/files/media_asset/ unaids-data-2018_en.pdf. 
2. Taiwo O. Dental practice, human immunodeficiency virus transmission and occupational risks: views from a teaching hospital in Nigeria. Ann Med Health Sci Res 2014; 4 (Suppl 2): S94-S98.

3. Saki M, Mohammad Khan Kermanshahi S, Mohammadi E, Mohraz M. Perception of patients with HIV/AIDS from stigma and discrimination. Iran Red Crescent Med J 2015; 17: e23638.

4. Singh VP, Osman IS, Rahmat NA, Bakar NAA, Razak NFNA, Nettem S. Knowledge and attitude of dental students towards HIV/AIDS patients in Melaka, Malaysia. Malays J Med Sci 2017; 24: 73-82.

5. Nubed CK, Akoachere JTK. Knowledge, attitudes and practices regarding HIV/AIDS among senior secondary school students in Fako Division, South West Region, Cameroon. BMC Public Health 2016; 16: 847 .

6. Yousuf A. Awareness of HIV/AIDS infection and ethical concerns amongst dentistry students and auxiliary staff in a hospital setup in Kashmir, India. Int J Community Med Public Heal 2016; 3: 2850-2855.

7. Aggarwal A, Sheikh S, Pallagatti S, Bansal N, Goyal G. Comparison of knowledge, attitudes and behaviour of dental and nursing students towards HIV/AIDS. J Med Med Sci 2012; 3: 537-545.

8. Khosravanifard B, Rakhshan V, Ghasemi M, et al. Tehran dentists self-reported knowledge and attitudes towards HIV/AIDS and observed willingness to treat simulated HIV-positive patients. East Mediterr Health J 2012; 18: 928-934.

9. Leao JC, Ribeiro CM, Carvalho AA, Frezzini C, Porter S. Oral complications of HIV disease. Clinics (Sao Paulo) 2009; 64: 459-470.

10. Da Costa Vieira V, Lins L, Sarmento VA, Netto EM, Brites C. Oral health and health-related quality of life in HIV patients. BMC Oral Health 2018; 18: 151.

11. Benjamin RM. Oral health care for people living with HIV/AIDS. Public Health Rep 2012; 127 (Suppl 2): 1-2.

12. Saini R. Oral lesions: a true clinical indicator in human immunodeficiency virus. J Nat Sci Biol Med 2011; 2: 145-150.

13. Nugraha AP, Ernawati DS, Parmadiati AE, et al. Drug utilization study of antifungal therapy in HIV/AIDS patient with oral candidiasis at UPIPI RSUD, Dr. Soetomo Hospital. JIDMR 2018; 11: 131134.

14. Mensana MP, Ernawati DS, Nugraha AP, et al. Oral candidiasis profile of the Indonesian HIV-infected pediatric patients at UPIPI Dr. Soetomo General Hospital, Surabaya, Indonesia. HIV AIDS Rev 2018; 17: 272-277.

15. Campo J, Cano J, del Romero J, Hernando V, del Amo J, Moreno S. Role of the dental surgeon in the early detection of adults with underlying HIV infection/AIDS. Med Oral Patol Oral Cir Bucal 2011; 17: e401-e408.

16. Santella AJ, Conway DI, Watt RG. The potential role of dentists in HIV screening. Br Dent J 2016; 220: 229-233.

17. Zaninovic P, Natto ZS, Turner RL, et al. An innovative HIV training program for dental hygiene students. J Dent Hyg 2013; 87: 47-55.

18. Jafari A, Yazdani R, Khami MR, Mohammadi M, Hajiabdolbaghi M. Effect of an educational course at an Iranian dental school on students' knowledge of and attitudes about HIV/AIDS. J Dent Educ 2012; 76: 792-799.

19. Prabhu A, Rao AP, Reddy V, Krishnakumar R, Thayumanavan S, Swathi SS. HIV/AIDS knowledge and its implications on dentists. J Nat Sci Biol Med 2014; 5: 303-307.

20. Dhanya RS, Hegde V, Anila S, Sam G, Khajuria RR, Singh R. Knowledge, attitude, and practice towards HIV patients among dentists. J Int Soc Prev Community Dent 2017; 7 (Suppl 1): S1-S7.

21. Wang L, Santella AJ, Huang R, et al. Knowledge of HIV and willingness to conduct oral rapid HIV testing among dentists in Xian China. PLoS One 2015; 10: e0119274.

22. Oberoi SS, Marya CM, Sharma N, Mohanty V, Marwah M, Oberoi A. Knowledge and attitude of Indian clinical dental students towards the dental treatment of patients with human immunodeficiency virus (HIV)/acquired immune-deficiency syndrome (AIDS). Int Dent J 2014; 64: 324-332.
23. Kadeh H, Saravani S, Golzari P. Knowledge, attitude and practice of dentists towards patients with HIV, hepatitis B and hepatitis C infections. Avicenna J Dent Res 2014; 6: 1-6.

24. Park JC, Choi SH, Kim YT, et al. Knowledge and attitudes of Korean dentists towards human immunodeficiency virus/acquired immune deficiency syndrome. J Periodontal Implant Sci 2011; 41: 3-9.

25. Li R, Dong W, He W, Liu Y. Chinese dental students' knowledge and attitudes toward HIV/AIDS. J Dent Sci 2016; 11: 72-78.

26. Rungsiyanont S, Lam-Ubol A, Vacharotayangul P, Sappayatosok K. Thai dental practitioners' knowledge and attitudes regarding patients with HIV. J Dent Educ 2013; 77: 1202-1208.

27. Aggarwal A, Panat SR. Knowledge, attitude, and behavior in managing patients with HIV/AIDS among a group of Indian dental students. J Dent Educ 2013; 77: 1209-1217.

28. Ryalat ST, Sawair FA, Shayyab MH, Amin WM. The knowledge and attitude about HIV/AIDS among Jordanian dental students: (clinical versus pre clinical students) at the University of Jordan. BMC Res Notes 2011; 4: 191.

29. Myers JE, Myers R, Wheat ME, Yin MT. Dental students and bloodborne pathogens: occupational exposures, knowledge, and attitudes. J Dent Educ 2012; 76: 479-486.

30. Ellepola AN, Sundaram DB, Jayathilake S, Joseph BK, Sharma PN. Knowledge and attitudes about HIV/AIDS of dental students from Kuwait and Sri Lanka. J Dent Educ 2011; 75: 574-581.

31. Patil PB, Sreenivasan V, Goel A. Knowledge of HIV/AIDS and attitude of dental students towards HIV/AIDS patients: a cross-sectional survey. J Educ Ethics Dent 2011; 1: 59-63.

32. Oboro HO, Azodo CC, Sede MA. Perception of HIV/AIDS among preclinical dental students. J Prev Med Hyg 2010; 51: 164-169.

33. Sadeghi M, Hakimi H. Iranian dental students' knowledge of and attitudes towards HIV/AIDS patients. J Dent Educ 2009; 73: 740-745.

34. Khan SA, Liew ML, Omar H. Role of ethical beliefs and attitudes of dental students in providing care for HIV/AIDS patients. Saudi Dent J 2017; 29: 7-14.

35. Neenu E, Sharma V, Bhat PK, Alashetty P. Barriers in providing dental treatment to HIV/AIDS patients. International Journal of Contemporary Medical Research 2017; 4: 1402-1405.

36. Nasir EF, Astrøm AN, David J, Ali RW. HIV and AIDS related knowledge, sources of information and reported need for further education among dental students in Sudan - a cross-sectional study. BMC Public Health 2008; 8: 286

37. Hamershock RA, Rajabiun S, Fox JE, et al. Dental students' HIV/ AIDS-related knowledge, attitudes, and intentions: impact of the U.S. Health Resources and Services Administration's community-based dental partnership program. J Dent Educ 2014; 78: 1106-1117. 